\section{Increasing Stock Production of Two Herbaceous Perennials with the Application of Plant Growth Regulators}

\author{
Sean J. Markovic ${ }^{1}$ and James E. Klett ${ }^{1}$
}

ADDITIONAL INDEX WORDs. coral bells, Heuchera sanguinea, propagation, stock plant management, vegetative cuttings, Zauschneria

SUMMARY. The objective of these experiments was to evaluate the reaction of 'Snow Angel' coral bells (Heuchera sanguinea) and Orange Carpet hummingbird trumpet (Epilobium canum ssp. garrettii 'PWWG01S') to repeated foliar applications of three plant growth regulators at two application rates. The plant growth regulators applied during a stock plant study and followed by a propagation study were 200 and $400 \mathrm{ppm}$ ethephon, 250 and $500 \mathrm{ppm}$ benzyladenine, and 50 and $100 \mathrm{ppm}$ gibberellic acid 4 and $7\left(\mathrm{GA}_{4+7}\right)+$ benzyladenine. The stock plant study was conducted to assess the efficacy of plant growth regulators, vegetative growth (height and width growth index), the number of vegetative cuttings, as well as the fresh weight (FW) and dry weight (DW) of the harvested vegetative cuttings. The propagation study was conducted to determine the effects of the plant growth regulator treatments on the rooting of the vegetative cuttings. The stock plant study showed that $\mathrm{GA}_{4+7}+$ benzyladenine (50 and $100 \mathrm{ppm}$ ) significantly increased production of 'Snow Angel' coral bells cuttings compared with all other treatments. However, no significant differences in FW or DW were observed with 'Snow Angel' coral bells between treatments. In the propagation study, no significant difference in rooting percentage was observed after 4 weeks. The Orange Carpet hummingbird trumpet stock plant study resulted in a greater number of vegetative cuttings with $\mathrm{GA}_{4+7}+$ benzyladenine $(50$ and $100 \mathrm{ppm})$ and benzyladenine $(250 \mathrm{ppm})$ treatments. Fresh weight of vegetative cuttings harvested from plants treated with $\mathrm{GA}_{4+7}+$ benzyladenine $(50$ or $100 \mathrm{ppm})$ were the lowest. The only treatment that showed increased vegetative cutting production with no effect on FW was benzyladenine (250 ppm) on Orange Carpet hummingbird trumpet.

$\mathrm{W}$ ithin stock plant production systems, herbaceous perennial crops need to produce enough vegetative material to justify the cost of the space that they occupy on the greenhouse bench. Although harvesting cuttings before bloom time is not preferred (Walters, 1982), taking cuttings year-round is a challenging task because perennials flower at different times during the year. Studies have shown that the reproductive tissue on cuttings can

Received for publication 28 Aug. 2019. Accepted for publication 23 Mar. 2020

Published online 12 May 2020.

${ }^{1}$ Department of Horticulture and Landscape Architecture, Colorado State University, 301 University Avenue, Fort Collins, CO 80523-1173

Mention of a trademark, proprietary product, or vendor does not constitute a guarantee or warranty of the product by Colorado State University and does not imply its approval to the exclusion of other products or vendors that also may be suitable.

J.E.K. is the corresponding author. E-mail: jim.klett@ colostate.edu.

This is an open access article distributed under the CC BY-NC-ND license (https://creativecommons.org/ licenses/by-nc-nd/4.0/).

https://doi.org/10.21273/HORTTECH04492-19 inhibit root and vegetative development (Gibson and Cerveny, 2005); therefore, it is highly desirable to keep stock plants in a juvenile or vegetative state of development. Because the success of propagating vegetative cuttings will depend on the propagator's judgment (Wells, 1971), producing stock plants with more available vegetative material during the growing season would certainly increase the propagator's options.

To achieve target uniformity, perennial producers often prune their plants manually, or, although less common, the use of plant growth regulators to enhance vegetative plant growth and remove reproductive tissue (Preece and Read, 1993). However, manually pruning perennials to encourage vegetative growth can be labor intensive (Banko and Stefani, 1996) and add additional unwarranted expense (Holland et al., 2007). Applying plant growth regulators, on the other hand, is generally less labor intensive than manual pruning, although there is a chance it can cause phytotoxicity in certain crops (Meijón et al., 2009). Three specific plant growth regulators have been identified for their potential benefits in stock plant production: gibberellic acid, benzyladenine, and ethephon.

Gibberellic acid 4 and $7\left(\mathrm{GA}_{4+7}\right)$ is a plant growth regulator that has been isolated from species of the fungus, Gibberella fujikuroi, and were first found in Japan in 1926 by E. Kurosawa (Salisbury and Ross, 1969). GA 4 promotes growth primarily through cell enlargement that is uniform throughout plant tissue. $\mathrm{GA}_{4+7}$ also hydrolyzes starch into sugar, which, in turn, provides energy and encourages uptake of water by cells; cell wall elasticity is another result of GA activity in the cell (Moore, 1984). Therefore, the application of $\mathrm{GA}_{4+7}$ to promote plant growth could result in more available propagation material from stock plants.

Cytokinins, specifically benzyladenine, have been found to be involved in nearly all aspects of plant growth and development (Leopold and Kreidermann, 1975). Benzyladenines are known for cell enlargement, not cell elongation as with auxins and GA. They promote cell growth in all directions (Preece and Read, 1993), which can result in the decrease of apical dominance if cytokinin levels in the plant are elevated (Hartmann et al., 2002). Therefore, increased lateral growth could be used to obtain more propagation material from stock plants.

The third plant growth regulator, ethephon, is an ethylene inducer

\begin{tabular}{llll}
\hline $\begin{array}{l}\text { Units } \\
\text { To convert U.S. to SI, } \\
\text { multiply by }\end{array}$ & U.S. unit & SI unit & $\begin{array}{l}\text { To convert SI to U.S., } \\
\text { multiply by }\end{array}$ \\
\hline 0.0929 & $\mathrm{ft}^{2}$ & $\mathrm{~m}^{2}$ & 10.7639 \\
3.7854 & $\mathrm{gal}$ & $\mathrm{L}$ & 0.2642 \\
2.54 & inch $(\mathrm{es})$ & $\mathrm{cm}$ & 0.3937 \\
1 & $\mathrm{mmho} / \mathrm{cm}$ & $\mathrm{mS} \cdot \mathrm{cm}^{-1}$ & 1 \\
28.3495 & $\mathrm{oz}$ & $\mathrm{g}$ & 0.0353 \\
1 & $\mathrm{ppm}$ & $\mathrm{mg} \cdot \mathrm{L}^{-1}$ & 1 \\
$\left({ }^{\circ} \mathrm{F}-32\right) \div 1.8$ & ${ }^{\circ} \mathrm{F}$ & ${ }^{\circ} \mathrm{C}$ & $\left({ }^{\circ} \mathrm{C} \times 1.8\right)+32$
\end{tabular}


that enters the plant and breaks down into three molecules: phosphate, chloride, and ethylene. These molecules are released into the plant systems, effecting plant growth and reproductive development (Preece and Read, 1993). Ethephon is widely used to promote auxiliary shoot development without damage to the apical meristem (Hayashi et al., 2001). Therefore, an increase in branching and a decrease in flower development could result in significantly more vegetative growth on herbaceous perennial stock plants. to plant growth regulators can vary across cultural and environmental conditions (Cochran and Fulcher, 2013). Previous research that involved herbaceous perennial liners with applications of $300,600,900$, or $1200 \mathrm{ppm}$ benzyladenine showed increased branching on 'Ruby Star' coneflower (Echinacea) at rates as low as $\mathbf{3 0 0}$ ppm (Latimer et al., 2011), while 'Silver Lode' coral bells responded minimally to an application of 600 ppm benzyladenine for both plant height and width (Latimer and Freeborn, 2015). The wide range of possible plant responses indicates the importance of studying two determining factors: 1 ) the rate and application timing based on the target crop and 2) the effect on plant growth the producer is trying to achieve (Cochran and Fulcher, 2013).

The herbaceous perennials used in these studies were 'Snow Angel' coral bells (Heuchera sanguinea) and Orange Carpet hummingbird trumpet (Epilobium canum ssp. garrettii 'PWWG01S'). During meetings with greenhouse and nursery operators who are propagating the two herbaceous perennial plants, they identified two main production problems with both 'Snow Angel' coral bells and Orange Carpet hummingbird trumpet: 1) the lack of vegetative propagation material from stock plants and 2 ) low rooting percentage rates during propagation. On the basis of previous research, it was determined that using plant growth regulators could resolve both problems.

The overall objective of these studies was to evaluate vegetative and floral development of 'Snow Angel' coral bells and Orange Carpet hummingbird trumpet after applications of three commercially available plant growth regulators with the active
Herbaceous perennial responses ingredients: GA, benzyladenine, or ethephon. The hypothesis of this study was that applications of plant growth regulators would result in increased vegetative propagation material from 'Snow Angel' coral bells and Orange Carpet hummingbird trumpet stock plants and not affect rooting success.

\section{Materials and methods}

STOCK PLANT STUdy. In the stock plant study, 'Snow Angel' coral bells and Orange Carpet hummingbird trumpet stock plants were grown and treated with three plant growth regulators to determine if they would produce more ideal cuttings (Fig. 1). Two experiments, referred to as 2016 and 2017, respectively, were conducted. The first experiment was conducted during Fall and Winter 201617 and repeated in Summer and Fall 2017. The materials and methods used in these experiments had a few differences that are noted in the appropriate places.

All experiments were conducted at Colorado State University Horticulture Center, Fort Collins (lat. $40.577953^{\circ} \mathrm{N}$, long. $105.080925^{\circ} \mathrm{W}$; U.S. Department of Agriculture hardiness zone $5 b$ ). Plants of uniform size (72-plug tray) were purchased from a local greenhouse (Gulley Greenhouse, Fort Collins, CO). Eighty-four plants of each perennial type were potted into black \#1 (0.75 gal) containers on 21 Sept. 2016 and 8 July 2017. The medium used for this study was a bark mix of intermediate particle

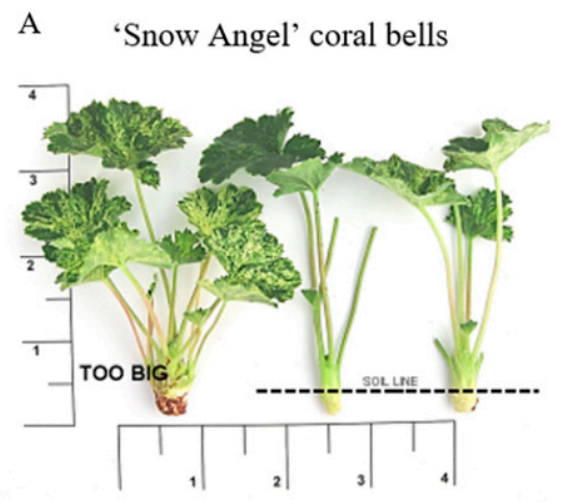

B 'Orange Carpet' hummingbird trumpet

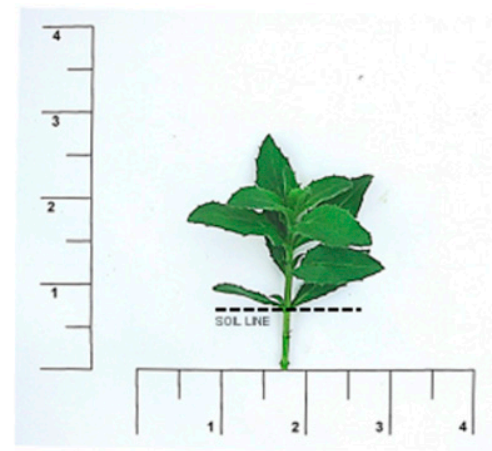

Fig. 1. Visual guide for 'Snow Angel' coral bells and Orange Carpet hummingbird trumpet cutting protocol provided by Gulley Greenhouse, Fort Collins, CO. Cuttings show the ideal size and preparation for harvest. Ideal size for cuttings are unlabeled, and one undesirable size is labeled TOO BIG. Measurements in inches $(1$ inch $=2.54 \mathrm{~cm})$.

size that included coarse peatmoss, perlite, dolomitic and calcitic lime, and a nonionic wetting agent (BM-7; Berger, Saint-Modeste, QC, Canada). Four replicates of three (12 total plants) were then placed in a complete randomized design and placed 12 inches apart on the greenhouse bench for each treatment.

During establishment, plants were watered by hand with $14 \mathrm{~N}-$ 1.7P-11.6K water-soluble fertilizer (GreenCare; Blackmore Co., Belleville, MI) at a rate of $200 \mathrm{ppm}$. Fertilizer was continuously injected using an inline, water-powered, nonelectric chemical injector (model Dl4MZ2; Dosatron, Clearwater, FL). Drip irrigation was installed after 5 weeks when the majority of the plants' roots began to strike the sides of the \# 1 containers, and the fertilizer regimen was switched to a continual feed $20 \mathrm{~N}-4.4 \mathrm{P}-16.6 \mathrm{~K}$ water-soluble fertilizer (Grow More, Gardena, CA) at a rate of $200 \mathrm{ppm}$. Electrical conductivity (EC) was checked once per month to determine whether there was salt buildup on each perennial. All readings fell within 0.25 and 1.6 $\mathrm{mS} \cdot \mathrm{cm}^{-1}$, and no symptoms of high salt levels were observed; therefore, data are not presented.

Using 0.5-gal/h emitters (Rain Bird Corp., Azusa, CA), drip irrigation initially ran twice weekly for 30 $\mathrm{min}$, for a total of $0.5 \mathrm{gal}$ of water per week per plant. In Jan. 2017, the irrigation was increased to every other day for an average of $l$ gal of water per 
week per plant. A second experiment in 2017 was conducted in the same for the drip irrigation, which initially ran three times weekly for $30 \mathrm{~min}$, for a total of $0.75 \mathrm{gal}$ of water per week per plant.

Initially, daytime temperatures (model M4821; Wadsworth Control Systems, Arvada, CO) sensor between 62 and $70{ }^{\circ} \mathrm{F}$, and nighttime temperatures were held between 58 and $70^{\circ} \mathrm{F}$. The temperature ranges were adjusted in late Dec. 2016 to help control powdery mildew (Podoshaera sp.) on 'Snow Angel' coral bells. For the remainder of the study, daytime temperatures were held between 65 and $73^{\circ} \mathrm{F}$, and nighttime temperatures were held between $6 \mathrm{l}$ and $73^{\circ} \mathrm{F}$. Before starting the second experiment, greenhouse temperatures were adjusted and held between 62 and $68{ }^{\circ} \mathrm{F}$ during the day with a nighttime range of 55 to $62^{\circ} \mathrm{F}$, to suppress flowering on Orange Carpet hummingbird trumpet stock plants (Table 1). For the second experiment, Orange Carpet hummingbird trumpet stock plants were moved closer to the pad wall in the greenhouse. This resulted in cooler temperatures and larger, more vegetative plants. This response was previously observed in the hummingbird trumpet (Epilobium sp.) under cooler temperatures (Anderson and Rupp, 2012).

In the first stock plant experiments, supplemental lighting was provided in two specific ways for each perennial. Light emitting diode (LED) fixtures manner for both perennials, except were maintained with an aspirator

(Green Power LED Toplighting Module DR/W MB 200-400V; Philips, Amsterdam, The Netherlands) provided $\approx 90 \%$ red and $10 \%$ blue light from sunrise to sunset every day throughout the greenhouse. A secondary set of red lights was applied only to Orange Carpet hummingbird trumpet subjects for night interruption (10:00 PM to 2:00 AM) to help control short-day blooms. Light readings were taken using a light sensor (LI-190; LI-COR, Lincoln, NE) to ensure there was no red-light bleeding across the greenhouse to disrupt the other perennials in the study. The secondary lighting did not produce positive results for reducing flowering in Orange Carpet hummingbird trumpet; therefore, no secondary lighting for night interruption was implemented during the second stock plant experiment in 2017.

Plant growth Regulator Application. The three plant growth regulators in this study were applied at two rates to both perennials simultaneously: ethephon: 200 and 400 ppm (Nufarm Americas, Alsip, IL), benzyladenine: 250 and $500 \mathrm{ppm}$ (Fine Agrochemicals, Worcester, UK), and $\mathrm{GA}_{4+7}$ + benzyladenine: 50 and 100 ppm (Valent USA Corp., Fresno, CA). Treatments in both experiments were applied 2 weeks before each monthly data collection over a 4-month period. In the first experiment, treatments were applied on 13 Nov. 2016, 13 Dec. 2016, 12 Jan. 2017, and 14 Feb. 2017. In the second experiment, treatments were

Table 1. Average daily day and night greenhouse temperatures for Expts. 1 and 2 conducted in 2016 and 2017 on 'Snow Angel' coral bells and Orange Carpet hummingbird trumpet. Data were compiled using an environmental control system (Wadsworth Control Systems, Arvada, CO) in a greenhouse at Colorado State University Horticulture Center, Fort Collins.

\begin{tabular}{lcc}
\hline Month & Avg day temp $\left({ }^{\circ} \mathbf{F}\right)^{\mathbf{z}}$ & Avg night temp $\left({ }^{\circ} \mathbf{F}\right)$ \\
\hline Expt. 1 & & \\
Oct. 2016 & 69.84 & 61.75 \\
Nov. 2016 & 67.19 & 59.41 \\
Dec. 2016 & 63.77 & 58.80 \\
Jan. 2017 & 67.37 & 61.47 \\
Feb. 2017 & 69.37 & 61.84 \\
Mar. 2017 & 71.33 & 62.91 \\
Expt. 2 & & \\
July 2017 & 70.92 & 64.43 \\
Aug. 2017 & 68.32 & 62.55 \\
Sept. 2017 & 63.34 & 60.84 \\
Oct. 2017 & 64.17 & 57.70 \\
Nov. 2017 & 63.45 & 56.64 \\
\hline
\end{tabular}

${ }^{z}\left({ }^{\circ} \mathrm{F}-32\right) \div 1.8={ }^{\circ} \mathrm{C}$. applied on 12 Aug. 2017, 12 Sept. 2017, 14 Oct. 2017, and 12 Nov. 2017. Treatments were applied to foliar runoff of the plants, including those in the control group, which were sprayed with plain water, using a l-gal hand-pump sprayer.

Data collection. To establish a baseline for this study, initial measurements of the height and two widths of each plant in the \#l containers were taken at 5 weeks, before the first application of the plant growth regulator treatments. Subsequently, plant height, width, number of cuttings, total FW of cuttings, and total DW of cuttings, were measured monthly on the same day the plant growth regulator treatments were applied. Plants were measured in centimeters at their highest point, from the base of the plant and at two cross widths at a $90^{\circ}$ angle. These three values were added together and divided by three to determine the growth index (GI) for each plant.

When harvested, two-thirds of the total vegetative growth of the stock plant was left intact to ensure continual plant growth throughout the time period, as suggested by commercial growers during development meetings. Cuttings were harvested monthly, $\approx 2$ weeks after the plant growth regulator treatment applications; ideal cuttings are indicated in Fig. 1. The ideal 'Snow Angel' coral bells cutting has up to a 4 -inch height and a stem with a 0.25 - to 0.5 inch diameter. The ideal Orange Carpet hummingbird trumpet cutting has up to a 3 -inch height and a stem with a 0.5 -inch portion without leaves. Next, cuttings from each stock plant were counted, weighed to determine the $\mathrm{FW}$ in grams, then placed in a drying oven at $70{ }^{\circ} \mathrm{C}$ for $48 \mathrm{~h}$ to determine the DW in grams. The harvested stock plants were grown for another 4 weeks before another harvest was taken. One month after the last cuttings were harvested for each experiment, 9 of the 12 stock plants from each treatment had all the shoot growth above the soil line removed, dried, and weighed. This was performed to approximate the average growth of the plant tops for each treatment.

Propagation study. After each stock plant experiment, a propagation experiment was performed. Three stock plants for each treatment were 
randomly selected for each experiment and continued to be grown under the same conditions as in the stock production experiments. The only variable continued to be the different plant growth regulators applied during the stock plant treatments. Three replications for each experiment were conducted with 10 cuttings being rooted in a randomized design in one propagation flat. Cuttings from each treatment were harvested every 4 weeks: 16 May 2017, 13 June 2017, and 11 July 2017 for the first experiment and 11 Jan. 2018, 8 Feb. 2018, and 1 Mar. 2018 for the second experiment. 'Snow Angel' coral bells cuttings were taken in the morning before 11:00 AM and dipped for $5 \mathrm{~s}$ in $500 \mathrm{ppm}$ indole-3-butyric acid (IBA)/l-naphthylacetic acid (NAA) (Dip 'N Gro, Clackmas, OR). Orange Carpet hummingbird trumpet cuttings were propagated without a rooting hormone. Orange Carpet hummingbird trumpet were propagated in trays of 98 cells of peatmoss and binding agent, and 'Snow Angel' coral bells were propagated in trays with 72 cells of peatmoss and binding agent (Preforma; Jiffy, Lorain, $\mathrm{OH}$ ).

A mist timer (NOVA 1626ET; Phytotronics, Earth City, MO) was used to control the amount of moisture administered on the cuttings which were under mist nozzles (03034211-b pcs 25 coolpro c $4 \times 7$ head $+\operatorname{ad} 20$; Netafim, Fresno, CA). Bottom heat was provided by heating mats (Redi Heat model RHD 2110, Phytotronics) at temperatures of 65 and $75^{\circ} \mathrm{F}$ for 'Snow Angel' coral bells and Orange Carpet hummingbird trumpet, respectively. During that time, cuttings were misted for $10 \mathrm{~s}$ throughout the $24 \mathrm{~h}$ day at varying time intervals each week, as follows: week 1 , every $15 \mathrm{~min}$; week 2 , every $30 \mathrm{~min}$; and weeks 3 and 4 every 60 min. Rooting data were collected every week for 4 weeks. The data collected was rooting success percentage during weeks 2 to 4 on the mist bench. Also, the number of visible roots were determined by counting to 50 individual roots in the cell. The rooting success and number of visible roots provided data to determine the effect of treatment on rooting and the quality of the rooted plant.

EXPERIMENTAL ANALYSIS. Data analysis was performed using statistical software ( $\mathrm{R}$ version 3.3.1; R Foundation for Statistical Computing, Vienna, Austria) with car, LSMeans, and ggplot packages; a one-way analysis of variance was run separately for the response variables. Response variables, with a sample size of 48 , included the average number of cuttings per plant, the average number of cuttings per square foot, the average FW per cutting, the average DW per cutting, and the final average DW of total shoot growth from each stock plant replicant. The data were analyzed and averaged over the four collections taken in both 2016 and 2017 and were specific to each year. Included in the statistical models were predictor variables matching the plant growth regulator treatments. Pairwise comparisons and least squares means were calculated using the LSmeans package for each response variable. Tukey adjusted pairwise comparisons were considered, and significant differences were noted using $\alpha=0.05$.

\section{Results}

'Snow Angel' Coral Bells. The data for these experiments was averaged across all four harvest dates. This was performed to give an overall view of the effects of plant growth regulators on stock production for a commercial grower. The data did not indicate statistical differences among the four harvest dates. For 'Snow Angel' coral bells, foliar sprays containing 50 and 100 ppm $\mathrm{GA}_{4+7}+$ benzyladenine increased the number of cuttings harvested when compared with all other treatments in 2016 and 2017 (Table 2). For example, plants treated with $\mathrm{GA}_{4+7}+$ benzyladenine (100 ppm) produced $2.4(22.5 \%)$ more cuttings in 2016, compared with the control group (Table 2). While plants treated with $\mathrm{GA}_{4+7}+$ benzyladenine $(50 \mathrm{ppm})$ produced $1.62(24.9 \%)$ more cuttings in 2017 compared with the control group.

Fresh weight was measured individually immediately after harvesting the cuttings from stock plants and used to determine the quality of the harvested vegetative cutting. Fresh weight was highest with $\mathrm{GA}_{4+7}+$ benzyladenine in 2017 compared with all other treatments (Table 2). However, the control group produced the highest FW per individual cutting in 2016. The control group in 2016 produced the lowest number of cuttings but with an average GI, which correlated with its larger-sized cuttings. The FW and DW in 2016 and 2017 resulted in no significant differences compared with the control group for benzyladenine treated plants (Table 2). These findings indicated no loss of cutting quality with the use of benzyladenine.

During the propagation study associated with each stock plant study, there was little evidence of the plant growth regulator's effect on the rooting percentage or the number of roots the vegetative cuttings produced. In 2016, cuttings had a lower overall average rooting percentage than in 2017 (data not shown). This could be attributed to rooting losses due to exhaust fan air movement affecting the mist system in 2016, which was corrected in 2017. In 2016, the control group had the highest rooting success at $93 \%$, while $\mathrm{GA}_{4+7}+$ benzyladenine $(100 \mathrm{ppm})$ had the lowest at $73 \%$. In 2017, benzyladenine ( $250 \mathrm{ppm})$ had a rooting success rate of $97 \%$, whereas ethephon (400 ppm) had the lowest at $77 \%$. None of the resulting probability values of the two experiments, for both rooting percentage and the number of visible roots, was lower than 0.319. This finding indicates there were no significant differences among the treatments and the overall successful rooting of 'Snow Angel' coral bells vegetative cuttings.

Orange Carpet Hummingbird Trumpet. Foliar sprays containing 50 and 100 ppm $\mathrm{GA}_{4+7}+$ benzyladenine increased the number of cuttings harvested when compared with all other treatments in 2016 and 2017 (Table 3 ). In 2016, there were no significant differences, whereas in 2017, there were significant differences in the average number of cuttings harvested. The FW and DW of the vegetative cuttings treated with $\mathrm{GA}_{4+7}+$ benzyladenine resulted in the lowest weights of any treatment for both experiments. The overall FW was heavier in 2016 than in 2017, resulting in a decrease of $68 \%$ (Table 3 ).

Benzyladenine appears to have the potential for limiting reproductive growth in Orange Carpet hummingbird trumpets. The additional lateral branches from the benzyladenine treatment were observed to have fewer flowers than the other treatments and control plants. Ethephon- 
Table 2. GI, number of cuttings harvested, fresh weight of individual cuttings, and dry weight of individual cuttings of 'Snow Angel' coral bells averaged over four harvest dates [ $n=48$ in Expt. 1 (2016) and Expt. 2 (2017)] as influenced by six plant growth regulator foliar treatments: benzyladenine at two rates $(250$ and $500 \mathrm{ppm})$, gibberellins A4A7 (GA) + benzyladenine at two rates $(50$ and $100 \mathrm{ppm})$, ethephon at two rates $(200$ and $400 \mathrm{ppm})$, and a control (water only). Experiments were performed in a greenhouse at Colorado State University Horticulture Center, Fort Collins.

\begin{tabular}{|c|c|c|c|c|c|}
\hline Treatment & Rate $(\mathrm{ppm})^{\mathrm{z}}$ & $\mathrm{GI}(\mathrm{cm})^{\mathrm{y}}$ & Cuttings (no.) & Fresh wt $(g)^{x}$ & Dry wt $(g)^{x}$ \\
\hline \multicolumn{6}{|l|}{2016} \\
\hline Control & & $10.81 \mathrm{a}^{\mathrm{w}}$ & $10.66 \mathrm{a}$ & $4.78 \mathrm{a}$ & $0.78 \mathrm{a}$ \\
\hline Benzyladenine & 250 & $10.77 \mathrm{a}$ & $11.97 \mathrm{abcd}$ & $4.44 \mathrm{a}$ & $0.76 \mathrm{a}$ \\
\hline Benzyladenine & 500 & $10.81 \mathrm{a}$ & $12.75 \mathrm{~cd}$ & $4.31 \mathrm{a}$ & $0.74 \mathrm{a}$ \\
\hline GA + benzyladenine & 50 & $11.14 \mathrm{a}$ & $12.47 \mathrm{bcd}$ & $4.49 \mathrm{a}$ & $0.71 \mathrm{a}$ \\
\hline GA + benzyladenine & 100 & $11.44 \mathrm{a}$ & $13.06 \mathrm{~d}$ & $4.56 \mathrm{a}$ & $0.72 \mathrm{a}$ \\
\hline$P$ value & & 0.365 & 0.029 & 0.607 & 0.687 \\
\hline \multicolumn{6}{|l|}{2017} \\
\hline Control & & $11.51 \mathrm{a}$ & $6.50 \mathrm{a}$ & $7.14 \mathrm{ab}$ & $1.54 \mathrm{ab}$ \\
\hline Benzyladenine & 250 & $11.03 \mathrm{a}$ & $7.08 \mathrm{ab}$ & $7.07 \mathrm{ab}$ & $1.47 \mathrm{ab}$ \\
\hline Benzyladenine & 500 & $11.23 \mathrm{a}$ & $7.50 \mathrm{ab}$ & $6.86 \mathrm{ab}$ & $1.41 \mathrm{ab}$ \\
\hline Ethephon & 400 & $12.28 \mathrm{a}$ & $6.83 \mathrm{ab}$ & $7.72 \mathrm{~b}$ & $1.62 \mathrm{~b}$ \\
\hline$P$ value & & 0.195 & 0.361 & 0.141 & 0.183 \\
\hline
\end{tabular}

treated plants at both rates resulted in more cuttings, with a comparable FW and DW for each experiment compared with the control group (Table $3)$.

During the propagation study for Orange Carpet hummingbird trumpets, there was little evidence of the plant growth regulators' effect on the rooting percentage of the vegetative cuttings. In 2016, cuttings that were propagated had an overall higher rooting percentage average than in 2017 (data not shown). The results for rooting percentage and the number of visible roots indicate there was not a significant difference in the treatment types or the overall successful rooting of Orange Carpet hummingbird trumpet vegetative cuttings.

\section{Discussion}

In the stock plant study of 'Snow Angel' coral bells, $\mathrm{GA}_{4+7}+$ benzyladenine resulted in more vegetative cuttings harvested compared with the other treatments. The added lateral growth due to the benzyladenine, combined with the elongation growth due to the $\mathrm{GA}_{4+7}$, produced more available cuttings. In addition, benzyladenine (250 and $500 \mathrm{ppm}$ ) resulted in a significant increase in the number of cuttings for harvest compared with the control group due to increases in lateral branching. 'Bressingham Bronze' coral bells treated with benzyladenine (1000 ppm) resulted in the effective release of lateral shoots (Martin and Singletary, 1999). Moreover, plants treated with $\mathrm{GA}_{4+7}+$ benzyladenine had the highest GI in 2016 and were only less than the ethephon (400 ppm) treatment in 2017. These results are similar to those by Ackerman and Hamernik (1994), who found an increase in early vegetative growth treated with $\mathrm{GA}_{3}(1000 \mathrm{ppm})$. The FW and DW of cuttings harvested for 'Snow Angel' coral bells showed no significant differences. The increased number of cuttings and lack of difference in the FW and DW indicated there was no adverse effect on cutting quality with increased growth. There was a marked difference in the average FW in 2016 compared with 2017; the cuttings from 2017 were $62 \%$ heavier.

Benzyladenine $(250$ and 500 $\mathrm{ppm}$ ) resulted in an increase in the number of cuttings harvested compared with the control group due to increased lateral branching. Another study showed that a single posttransplant application resulted in four times the number of leaders and lateral branches on 'Autumn Joy' stonecrop (Hylotelephium) than was found on the control plants (Latimer et al., 2013). Similar results were observed on lateral or basal branches and leaders treated with benzyladenine (300 and 600 ppm), which showed significant increases on some herbaceous perennial liners when treated with benzyladenine (Grossman et al., 2012). Orange Carpet hummingbird trumpet results were similar to previous perennial research findings.

Ethephon (200 and 400 ppm) resulted in similar growth to the control group with small increases in the number of cuttings harvested. The inclusion of ethephon in this study was based on previous research that plants treated with ethephon would maintain vegetative growth and induce abscission of flower buds (Walters and Lopez, 2018). No flowering was observed throughout the 
Table 3. GI, number of cuttings harvested, fresh weight of individual cuttings, and dry weight of individual cuttings of Orange Carpet hummingbird trumpet averaged over four harvest dates $[\mathrm{n}=48$ in Expt. 1 (2016) and Expt. 2 (2017)] as influenced by six foliar-applied plant growth regulator treatments: benzyladenine at two rates $(250$ and $500 \mathrm{ppm})$, gibberellic acid 4 and $7\left(\mathrm{GA}_{4+7}\right)+$ benzyladenine at two rates $(50$ and $100 \mathrm{ppm})$, and ethephon at two rates $(200$ and 400 ppm), and control with only water applied. Experiments were performed at the Colorado State University Horticulture Center greenhouse, Fort Collins.

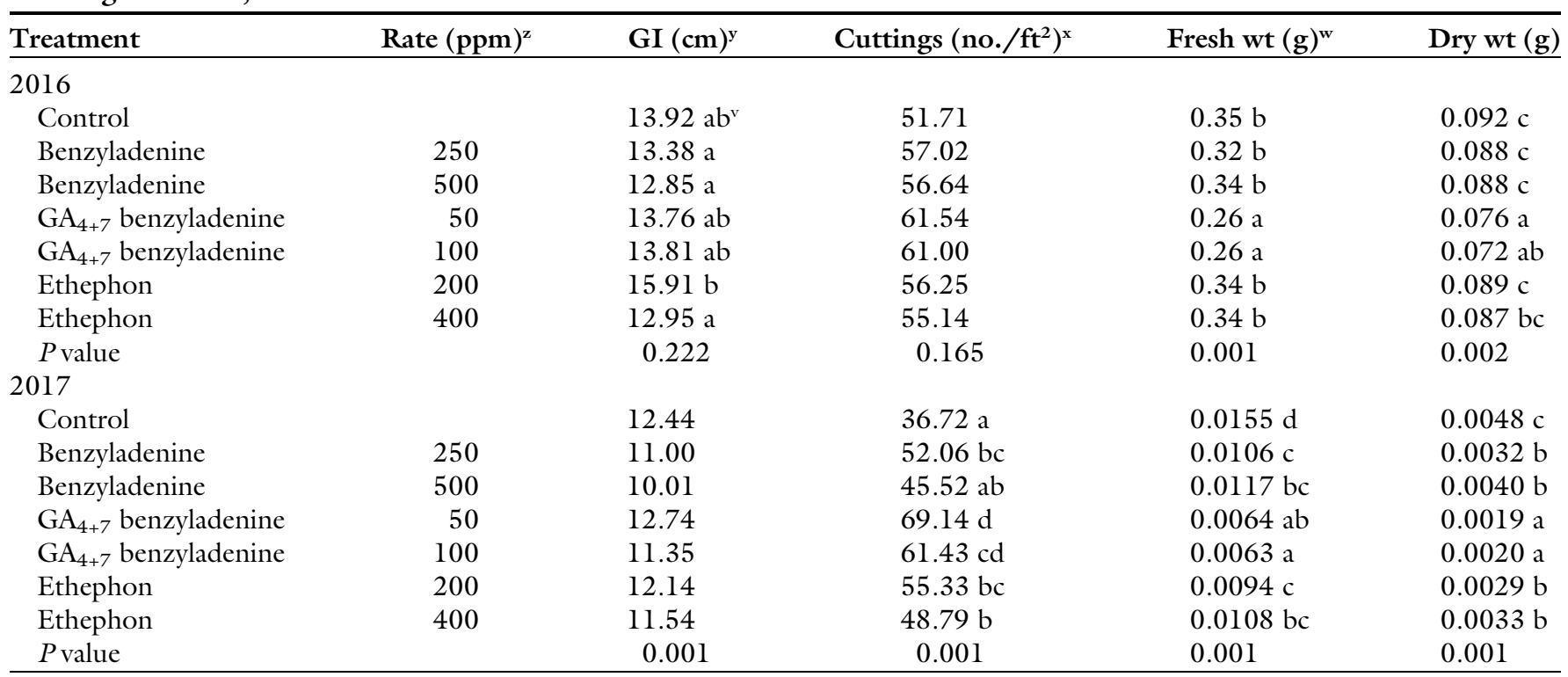

${ }^{\mathrm{z}} \mathrm{l} \mathrm{ppm}=1 \mathrm{mg} \cdot \mathrm{L}^{-1}$.

${ }^{y}$ Growth index (GI) determined from one height and two width measurements at the largest diameter cross-sections; GI $=($ height + width $1+$ width 2$) / 3 ; 1 \mathrm{~cm}=0.3937$ inch . ${ }^{\mathrm{x}} 1$ cutting $/ \mathrm{ft}^{2}=10.7639$ cuttings $/ \mathrm{m}^{2}$.

${ }^{\text {w}}$ Fresh and dry weights were taken as a whole for each plant harvested, and the average individual cutting weight was determined using total weight and dividing by the number of cuttings harvested from the single plant. $1 \mathrm{~g}=0.0353 \mathrm{oz}$.

${ }^{v}$ Mean separation in columns with Tukey adjusted least squares means at $P \leq 0.05$ (lowercase letters).

experiments with 'Snow Angel' coral bells for any of the treatments, and ethephon had little effect on increasing overall plant growth. Previous research of perennials, such as 'Cinnamon Red Hots' garden pinks ( $\mathrm{Di}$ anthus caryophyllus), showed that ethephon increased branching but had no effect on floral development. It was suggested that a higher rate (above $800 \mathrm{ppm}$ ) of ethephon may abort flowers in 'Cinnamon Red Hots' garden pinks. The lack of growth extension at the rates tested made harvesting cuttings difficult, which was also observed in this study at harvest dates (Glady et al., 2007). In this experiment, lateral growth for 'Snow Angel' coral bells and Orange Carpet hummingbird trumpet was increased, but the size of lateral shoots was too small for the cutting size parameters used (Fig. 1).

The effect of the different plant growth regulators applied to the stock plants had little effect on the successful propagation of 'Snow Angel' coral bells. In both 2016 and 2017 experiments, results indicated no statistical differences in the rooting percentage or the number of visible roots (data not shown). The increase in cuttings with applications of $\mathrm{GA}_{4+7}+$ benzyladenine had no evidence of a negative effect on rooting, which should benefit commercial producers. Another study was conducted after these experiments were finished to determine the potential longevity of the stock plant production. Over the additional 8-month period, the application of plant growth regulators was shown to maintain the increase in stock plant growth (Markovic and Klett, 2019).

Trends in each of the Orange Carpet hummingbird trumpet experiments were similar. $\mathrm{GA}_{4+7}+$ benzyladenine treated plants resulted in the highest number of cuttings harvested per plant. However, it resulted in the lowest FW and DW, which affected the overall quality of the vegetative growth (Table 3 ). Moving the stock plants from the warmest to coolest location in the greenhouse resulted in a visible difference in the number of flowers the plants produced. This could also be the reason for the decrease in FW and DW from 2016 to 2017 with Orange Carpet hummingbird trumpet, as seen previously with hummingbird trumpet (Anderson and Rupp, 2012).

The excess flowering in 2016 was evident in plants with thicker reproductive growth, which could explain the overall FW difference between the two experiments. In 2017, the control plants were observed to flower more profusely than the treated plants, which resulted in a lower number of cuttings harvested. All of the plant growth regulator treatments decreased the amount of Orange Carpet hummingbird trumpet's reproductive tissue to some extent through increased lateral growth, making it impossible to move into the reproductive growth cycle before the next harvest date. The decreased reproductive tissue was determined to be the biggest factor in loss of available vegetative material.

Previous research of other perennials has shown that the number of shoots per pot treated with ethephon (1000 ppm) varied by species, with increases in 'Weser River Sandstone' yarrow (Achillea millefolium) and 'Moonbeam' tickseed (Coreopsis verticillata), whereas 'Thomas Killen' shasta daisy (Leucanthemum $\times$ superbum) and 'Blue Stocking' beebalm (Monarda didyma) had a decrease in shoots per 
pot (Hayashi et al., 2001). These inconsistent findings provide some evidence as to why ethephon increased the number of Orange Carpet hummingbird trumpet cuttings but not the number of 'Snow Angel' coral bells.

The propagation study had different overall rooting rates between 2016 and 2017. Decreased flowering of the stock plants from 2016 to 2017 was partially responsible for the difference. Also, environmental conditions on the propagation mist bench contributed to the increase in rooting success. In 2016, the exhaust fans in the greenhouse pulled away mist from Orange Carpet hummingbird trumpet flats, and the cuttings dried out quickly. During 2017, a plastic wall was constructed around the mist bench to eliminate this environmental variable, which increased the mist droplets that remained around the cuttings on the bench.

\section{Conclusions}

This study determined whether $\mathrm{GA}_{4+7}+$ benzyladenine, benzyladenine, or ethephon applications can improve stock plant production in perennials. Production increased through maintained vegetative growth, improved cutting yield, or an acceptable rooting percentage. $\mathrm{GA}_{4+7}+$ benzyladenine appears to have the greatest potential for these promising outcomes in 'Snow Angel' coral bells because of the increase in internodal growth during the 1month intervals between harvests. However, benzyladenine appears to have the most potential for increasing the number of Orange Carpet hummingbird trumpet cuttings by decreasing the growth of reproductive tissue on the plants.

\section{Literature cited}

Ackerman, R. and H. Hamernik. 1994. Gibberellic acid to extend shoots and bud break on Heuchera and Scabiosa. Proc. Intl. Plant. Prop. Soc. 44:545-546.

Anderson, R.M. and L.A. Rupp. 2012. Selecting and evaluating accessions of Epilobium sect. Zauschneria (Onagraceae $)^{\odot}$. Proc. Intl. Plant. Prop. Soc. 62:146-149.

Banko, T.J. and M.A. Stefani. 1996. Growth response of large, established shrubs to cutless, atrimmec, and trimcut. J. Environ. Hort. 14:177-181.

Cochran, D. and A. Fulcher. 2013. Type and rate of plant growth regulator influence vegetative, floral growth, and quality of Little Lime ${ }^{\mathrm{TM}}$ hydrangea. HortTechnology 23:306-311.

Gibson, J.L. and C.B. Cerveny. 2005. Stock plant production and management basics for small greenhouse businesses. Univ. Florida Ext. Bul. ENH1021. 10 Oct. 2017. <http://ufdcimages.uflib.ufl. $\mathrm{edu} / \mathrm{IR} / 00 / 00 / 17 / 42 / 00001 /$ EP28400.pdf>.

Glady, J.E., N.S. Lang, and E.S. Runkle. 2007. Effects of ethephon on stock plant management of Coreopsis verticillata, Dianthus caryophyllus, and Veronica longifolia. HortScience 42:1616-1621.

Grossman, M., J. Freeborn, H. Scoggins, and J.G. Latimer. 2012. Benzyladenine increases branching but reduces root growth of herbaceous perennial liners. HortScience 47:1085-1090.

Hartmann, H.T., D.E. Kester, F.T. Davies, and R.L. Geneve. 2002. Plant propagation: Principles and practices. 7 th ed. Pearson Education, Upper Saddle River, NJ.

Hayashi, T., R.D. Heins, A.C. Cameron, and W.H. Carlson. 2001. Ethephon influences flowering, height, and branching of several herbaceous perennials. Scientia Hort. 91:305-323.

Holland, A.S., G.J. Keever, J.R. Kessler, and F. Dane. 2007. Single cyclanilide ap- plications promote branching of woody ornamentals. J. Environ. Hort. 25:139144.

Latimer, J.G., J. Freeborn, and V. Groover. 2011. Benzyladenine increases branching of herbaceous perennials. Acta Hort. 886:163-166.

Latimer, J.G., M. Grossman, and H. Scoggins. 2013. Improve branching of upright sedums with PGRs. E-GRO Alerts 2(13):1-4.

Latimer, J.G. and J. Freeborn. 2015. Improving quality of containerized herbaceous perennials with a tank mix of Configure and Piccolo. E-GRO Alerts $4(5): 1-5$.

Leopold, A.C. and P.E. Kriedemann. 1975. Plant growth and development. 2nd ed. McGraw-Hill, New York, NY.

Markovic, S.J. and J.E. Klett. 2019. How to know when your perennial cuttings are no longer productive. 19 Apr. 2019. <https://www.greenhousegrower.com/ production/how-to-know-when-yourperennial-cuttings-are-no-longerproductive $/>$.

Martin, S.A. and S. Singletary. 1999. N-6 Benzyladenine increases lateral offshoots in a number of perennial species. Proc. Intl. Plant. Prop. Soc. 49:329-334.

Meijón, M., R. Rodriquez, M. Canal, and I. Feito. 2009. Improvement of compactness and floral quality in azalea by means of application of plant growth regulators. Scientia Hort. 119:169-175.

Moore, G.M. 1984. Mechanisms of hormone action in plants. Proc. Intl. Plant. Prop. Soc. 34:79-90.

Preece, J.E. and P.E. Read. 1993. The biology of horticulture; an introductory textbook. Wiley, New York, NY.

Salisbury, F.B. and C. Ross. 1969. Plant physiology. Wadsworth, Belmont, CA.

Walters, J. 1982. Propagation of herbaceous perennials. Proc. Intl. Plant. Prop. Soc. 32:583-588.

Walters, K. and R. Lopez. 2018. The efficacy of ethephon foliar sprays is influenced by carrier water alkalinity and ambient air temperature at application. HortScience 53:1835-1841.

Wells, J.S. 1971. Plant propagation practices. Macmillan, New York, NY. 